\title{
DA DESNECESSIDADE DE EXISTENNCIA DE VIA ALTERNATIVA GRATUITA PARA ENSEJAR A COBRANÇA DO PEDÁGIO
}

\section{PARECER}

A cobrança do pedágio não viola o direito constitucional de ir e vir, porque está expressamente excepcionada no art. 150, V, da $C F$, que trata especificamente das vedações constitucionais ao poder de tributar, não abrangendo o pedágio, que é tarifa, paga pelo usuário do serviço, como remuneraçäc pelo serviço público prestado.

As disposições constitucionais do art. 150, V devem ser imterpretadas em conjunto com as constantes do art. 175. que trata da concessão de serviços públicos.

As Leis $n^{\circ}$ s 8.987/95 e 9.074/95 consagram a admissibilidade do regime da concessão, remunerada por pedágio, para toda e qualquer rodovia, independentemente de suas características e sem qualquer exigência quanto à existência de outra via alternativa gratuita para o usuário.

Não há disposição constitucional ou legal que condicione a cobrança de pedágio à existência de via alternativa gratuita para o mesmo trajeto.

A garantia do direito de locomoção expresso no art. $5^{\circ}, X X X V$, da CF é norma de eficácia contida e depende da regulação por legislação infraconstitucional, sendo que inexiste qualquer preceito legal que considere impeditiva ou violadora deste direito a cobrança do pedágio, mesmo que inexista outra rodovia gratuita, à disposição do usuário. 


\section{DA CONSULTA}

1. A empresa "A" honra-nos com uma consulta sobre a constitucionalidade e a legalidade da cobrança do pedágio em rodovias objeto de concessão no caso de inexistência de via alternativa gratuita.

2. A Consulente nos apresenta o seguinte quesito único:

"É requisito indispensável para a cobrança de pedágio em rodovia objeto de concessão a existência de via alternativa gratuita de trânsito?"

3. A resposta à questão formulada envolve o estudo do instituto do 'pedágio', examinado sob o enfoque do direito constitucional da liberdade de locomoção e das disposições constitucionais e infraconstitucionais pertinentes à concessão de serviços públicos.

4. Será analisado o posicionamento doutrinário e jurisprudencial sobre at matéria, para, finalmente. apresentarmos as conclusōes e a resposta ao quesito.

\section{DO PEDÁGIO NO DIREITO BRASILEIRO}

5. O pedágio foi a fórmula encontrada pelo Estado para construir e disponibilizar à população as estradas e rodovias em adequadas condições de uso. Foi previsto na Constituição Federal de 1946, como compensação assegurada ao Estado pelas despesas de construção, conservação e melhoramento das estradas, muito embora se tenha notícias acerca da cobrança de pedágio anteriormente.

6. Atualmente, a cobrança de pedágio está contemplada no art. $150, \mathrm{~V}$, da Constituição Federal, verbis:

"Art. 150. Sem prejuízo de outras garantias asseguradas ao contribuinte, é vedado à União, aos Estados, ao Distrito Federal e aos Municipios:

(...)

V - estabelecer limitações ao tráfego de pessoas ou bens, por meio de tributos interestaduais ou intermunicipais. ressalvada a co- brança de pedágio pela utilização de vias conservadas pelo Poder Público."

7. No plano infraconstitucional, o pedágio consiste em condição para que o usuário possa utilizar determinado bem público de uso comum - - a rodovia - condição esta perfeitamente admitida pela Lei $\mathrm{n}^{0} 10.406$, de 10.01.02 (Novo Código Civil), cujo art. 103. mantendo a norma prescrita pelo art. 68 do Código Civil de 1916, dispõe o seguinte:

"Art. 103. O uso comum dos bens públicos pode ser gratuito ou retribuido, conforme for estabelecido legalmente pela entidade a cuja administração pertencerem."

8. A Lei de Concessões também prevê expressamente a cobrança do pedágio, impondo aos usuários. em seu art. $7^{\circ}$, dentre outras obrigações. a de "contribuir para a permanência das boas condiçōes dos bens públicos através dos quais thes são prestados os serviços".

9. É importante considerar que, no atual contexto econômico, a cobrança de pedágio representa um instrumento imprescindível ao adequado funcionamento do sistema rodoviário, melhorando as condições físicas de pavimentação e sinalização das estradas e a adoção de mecanismos hábeis a trazer segurança e prevenção de acidentes, com benefícios ao tráfego e aos usuários. Por tais obras e serviços, no regime da concessão, pagam apenas os usuários da estrada, não constituindo um onus para toda a coletividade, como aconteceria se tais investimentos fossem suportados a partir do orçamento estatal.

10. A matéria, no entanto, tem gerado discussão doutrinária e jurisprudencial, tendo sido. no passado, suscitados argumentos no sentido da inviabilidade da cobrança do pedágio, quando não existir, para o mesmo percursoo, outra via de trânsito gratuita. A tese apoia-se no direito de locomoção de pessoas e bens, que estaria, sob tal ótica. sendo violado, invocando-se, para este fim, o art. 150, V, da Constituição Federal, que trata exclusivamente das limitações ao poder de tributar, excepcionando explicitamente o pedágio, que não tem natureza tributária, como será adiante exposto. 
11. No curso do presente parecer procurarse-á demonstrar que é viável a cobrança do pedágio sem a existência de via de trânsito gratuita, de acordo com o ordenamento jurídico brasileiro. examinando-se o regime do pedágio no direito constitucional $\mathrm{e}$ infraconstitucional.

\section{DA NATUREZA JURÍDICA DO PEDÁGIO}

12. Já se discutiu muito se o pedágio corresponderia a "taxa", isto é, uma espécie de tributo, ou a "tarifa", entendida esta como "preço público", despido de qualquer caráter tributário.

13. A questão gerou controvérsia desde a institucionalização do pedágio pela Constituição Federal de 1946, cujo art. 27 referia-se expressamente aos valores "destinados exclusivamente à indenização das despesas de construção, conservação e melhoramento de estradas" como taxa. Já naquela época, discutiu-se sobre a possibilidade de considerar o pedágio uma taxa sui generis, o que possibilitaria a sua cobrança por particulares ${ }^{\perp}$.

14. Na verdade, o pedágio não tem a natureza de tributo, mas constitui, na essência. um preço público (tarifa), e, nessa qualidade, não está adstrito à proibição constitucional para ser cobrado por concessionários, ou pelo próprio Estado, quando for ele o prestador do serviço.

15. Hely Lopes MEIRELLES analisa a natureza jurídica do pedágio, mostrando que a confusão entre os conceitos de taxa e tarifa nasce, muitas vezes, do próprio legislador:

"Por essas considerações se vê que a tarifa e a taxa têm natureza e finalidade diversas, embora ambas se destinem a remunerar atividades ou serviços prestados pelo Poder Pú- blico ou por seus delegados. Lamentável é que o legislador e o administrador, tão freqüentemente, confundam essas duas modalidades de remuneração, instituindo uma pela outra, ou sinonimizando os têrmos - taxa e tarifa - quando expressam conceitos fundamentalmente diversos e produzem consequiências jurídicas bem diferenciadas.

(...)

O pedágio é preço público (tarifa) e não tributo. Como preço público não está sujeito aos requisitos constitucionais dos tributos para a sua fixação e cobrança. É cobrável de quem utiliza espontaneamente o bem ou serviço tarifado, na forma autorizada por lei e no quantum fixado por decreto." 2

16. Há trinta e cinco anos, aliás, em parecer que demos a pedido da DERSA, já tivemos o ensejo de salientar a evolução que houve no direito brasileiro e estrangeiro para reconhecer que o pedágio é preço público.

17. Escrevemos então que:

"Tarifa ou preço público é uma receita do Estado de natureza contratual, não obrigatória, que corresponde a remuneração de um serviço prestado pela entidade de direito público, atendida sempre a equivalência das prestações recíprocas". (Bilac PINTO, Estudos de Direito Público, Edição da Revista Forense, 1953, p. 167) ${ }^{3}$

18. Na mesma ocasião, o Ministro Seabra Fagundes teve o ensejo de afirmar que:

"A fronteira entre o preço público e a taxa como contribuições devidas pelo indivíduo a troco de prestações emanadas do Estado (direta ou indiretamente), se mostra por vezes indecisa. Constitui mesmo torturante questão para os autores, até porque não solvida, na prática, pela simplificação de conceitos teóricos em que alguns escritores se comprazem. E a dificuldade cresce à proporção que, ex-

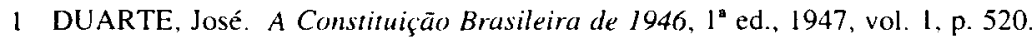

2 MEIRELLES, Helly Lopes. "Pedágio - Natureza Jurídica - Condições para sua cobrança", Revista de Direito Administrativo, vol. 104, p. 374-380.

3 WALD, Arnoldo. Parecer dado em 21 de novembro de 1969 e publicado na obra $O$ pedágio constitucionalidade e legalidade, sem data, p. 7. 
pandindo-se o campo de atividade administrativa do poder público, múltiplas modalidades se oferecem de atuação dele, seja na prestação de serviços de novo tipo, seja na prestação, sob novas características, de serviços já usualmente por ele prestados".'

19. Por isto se nos afigura que a razão está com SELLIGMAN, quando, sem embargo do apelo que faz ao elemento interesse, para distinguir preço público (retribuição de serviço prestado tendo em vista, principalmente, vantagem do indivíduo, e, em segundo lugar. interesse da comunidade), e taxa (retribuição de serviço prestado com vistas, principalmente, ao interesse público, mas conferindo ao contribuinte uma vantagem particular), reconhece não se apresentar, com nitidez, a distinção entre "um negócio naturalmente público e um negócio naturalmente privado", para admitir, como que no reconhecimento da inanidade prática da sua própria construção classificatória:

"A distinção não depende então, como tem acreditado a maior parte dos escritores, da natureza da empresa. De fato, a remuneração de unt mesmo serviço pode ser um preço em um Estado, uma taxa em outro e um imposto num terceiro ('Essais sur l'Impôst', versão francesa de Louis Suret, ed. M. Giard e E. Briére, vol. II, págs. 159, 160, 167, 174/5)".

20. Restaria, talvez, atenta a ressalva do eminente BALEEIRO, a faixa indelegável dos "serviços de autoridade" (" Uma Introdução à Ciência das Finanças", $1^{a}$ edição, vol. I, págs. 156-7). Faixa, ainda assim, não muito nítida, quando a política de segurança é tradicionalmente reconhecida aos concessionários de serviços públicos e a concernente à saúde pública tem sido cometida, entre nós, em campanhas sanitárias (nalária e febra amarela), a uma entidade privada (Fundação Rockefeller).

21. Na prática, a distinção se situa, em verdade, dentro da órbita do direito positivo. A configuração que este empresta a um serviço e à maneira da sua prestação é que resultará em caracterizá-lo como serviço explorável em regime de taxa ou de preço. "Um pagamento juridicamente - ensina Geraldo ATALIBA - configura o preço ou a taxa. conforme seu regime juridico" ("Considerações em torno da teoria jurídica da taxa", Revista de Direito Público, vol. 9, pág. 51).

22. Na espécie, porém, ainda para os que pretendem vincular a distinção entre taxa e preço público à natureza do serviço em si, negando ao legislador, pelo amoldamento, a seu juízo, do tipo de exploração, prescrever aos serviços públicos o regime que se lhe afigure conveniente. a controvérsia carecerá de importância, por força de texto constitucional.

23. Com efeito, a Constituição Federal (Emenda $\mathrm{n}^{\circ} 1$, no art. $8^{\circ}$ ) diz competir à União:

"XV - explorar, diretamente ou mediante autorização ou concessão":

“d) as vias de transporte entre portos marítimos e fronteiras nacionais ou que transponham os limites de Estado ou Território."

24. Tem, assim, que a exploração de vias de transporte (ferrovias, rodovias, aerovias e aquavias) se pode fazer em regime de concessão.

25. Se a carta Política tem como legítima a exploração de rodovias federais, através de concessão, é irrecusável aos Estados (e Municípios) socorrerem-se, na estrutura dos seus serviços administrativos, do mesmo critério adotado no plano federal. Fazendo-o, apenas adotam, na gestão dos seus serviços, critério de delegação reconhecido pelo texto constitucional, em princípio, como adequado à exploração de serviços rodoviários, ferroviários etc.

26. Ora, tendo previsto a exploração de vias de transporte mediante concessão, o texto constitucional admitiu virtualmente, se sujeite esse serviço ao regime de preços. Sim, porque a concessão supõe, necessariamente, remuneração do concessionário mediante pagamento da utilização pelos usuários, segun-

1 Seabra Fagundes, parecer datado de 28 de junho de 1971 e publicado na obra O pedágio constitucionalidade e legalidade, sem data, p. 42-43. 
do uma tarifa de preços (Emenda n. 1. art. 167). Preços que para as estradas de rodagem se traduzem no pedágio ou rodágio.

27. O que se escreveu a respeito da Constituição de 1967 e da Emenda Constitucional de 1969 continua a ser aplicável no direito constitucional vigente. Fica, pois, excluída a conceituação do pedágio como taxa, não se lhe aplicando os princípios que regem os tributos: a previsão em texto legal, a anterioridade e a anualidade (art. 150 da Constituição Federal de 1988).

28. A aplicação de tais princípios ao pedágio é, outrossim, absolutamente incompatível com o regime da concessão, como deflui dos textos anteriormente transcritos de Seabra FAGUNDES e da nossa autoria.

29. Certo é. ainda, que a Lei de Concessões refere-se à remuneração devida à concessionária pela utilização de serviço público concedido, em todo o seu texto, como tarifa, excluindo da fixação da mesma os princípios da legalidade ${ }^{l}$ e da anualidade?

30. Com efeito, a redação do parágrafo único. do art. 175. da Constituição Federal enuncia, dentre as matérias sobre as quais a lei ordinária deve dispor, na disciplina das concessões, a "política tarifária", que tem como essência a garantia ao concessionário do equilíbrio econômico-financeiro do contrato, conforme disposições da Constituição Federal ${ }^{3} \mathrm{e}$ da Lei de Concessõest.
31. Com efeito, não há como compatibilizar os princípios da anterioridade e da anualidade com o princípio do equilíbrio econômico-financeiro, inerente ao regime tarifário. $A$ inviabilidade é não só jurídica, como lógica e prática, considerando que a falta de revisão da tarifa, quando necessária, pode implicar em deficiência do serviço público, em razão da escassez de recursos para fazer frente às despesas e investimentos necessários à execução das obras e à prestação do serviço objeto da concessão.

32. Sobre o tema, assim se manifesta Celso Antônio BANDEIRA DE MELLO:

"Assim também, se o valor em questão se subordinasse aos princípios da anterioridade e da anualidade, como ocorre com a taxa, é bem de ver que a restauração do equilíbrio econômico-financeiro quando menos ficaria protraida, podendo inclasile, pelo decurso do tempo nisto implicado colocar-se para o concessionário situação de sufocação econômica, impossibilidade fática de prosseguir no ritmo das obras pressupostas na concessão. ou de declínio das atividades de conservação da via pública se este for o objeto concedido, dos reparos necessários ou da prestação dos serviços complementares, o que, a toda evidência, sobre contrariar o interesse público substanciado na relação jurídica travada

- O art $9^{\circ}$, caput e parágrafo $1^{\circ}$, da Lei de Concessōes, dispõe que "a tarifa do semiço público concedido será fixada pelo preço da proposta vencedora da licitaçäo e preservada pelas regras de revisão previstas nesta lei. no edital e no contrato" e que "a tarifa näo será subordinada à le gislação específica anterior..."

20 art. 23. da I le Concessões, estabelece que "são cláusulas essenciais do contrato de concessão as relativas: (...) 11 - ao preso do serviço e aos critérios e procedimentos para o reajtaste e a revisão das tarifus".

3 "Art. 37. A Administração pública direta e indireta de qualquer dos Poderes da União, dos Estados, do Distrito Federal e dos Municípios obedecerá aos princípios da legalidade, impessoalidade, moralidade, publicidade e eficiência e, também ao seguinte:

(...)

XXI - ressalvados os casos especificados na legislação, as obras, serviços, compras e alienações serão contratados mediante processo de licitaçāo pública que assegure igualdade de condiçōes a todos os concorrentes, com cláusulas que estabeleçam obrigaçōes de pagamento, mantidas as condiçōes efetivas da proposta. nos termos da lei, o qual somente permitirá as exigências de qualificação técnica e econômica indispensáveis à garantia do cumprimento das obrigações."

$4 \mathrm{O}$ art. $9^{\circ}, \$ 2^{\circ}$. estabelece, expressamente. que deve ser mantido o equilibrio econômico-financeiro da concessão. 
com o concedente, instabilizaria as próprias bases do instituto e a utilidade que lhe serve de justificativa."

33. Nem se diga que o art. 150, V, da Constituição Federal, ao excetuar a cobrança de pedágio pela utilização de vias conservadas pelo Poder Público da vedação imposta aos tributos caracterizaria o pedágio pago ao concessionário como taxa. A análise sistemática dos dispositivos constitucionais aplicáveis à matéria não deixa dúvidas de que a ressalva feita pelo legislador se refere exclusivamente ao pedágio cobrado nas rodovias exploradas diretamente pelo Estado.

34. Cumpre registrar que, no passado, apreciando a Lei $\mathrm{n}^{\circ} 7.712 / 88$, os Tribunais Regionais Federais tenderam a classificar o selo-pedágio como um tipo de tributo, com natureza jurídica similar a uma tax $\mathrm{a}^{2}$. Assim também entendeu o Supremo Tribunal Federal'. Mas não há como confundir o selo-pedágio com a cobrança do pedágio pelos concessionários.

35. Hoje, entretanto, podemos dizer que praticamente se consolidou o entendimento de que pedágio (ao contrário do selo-pedágio) é uma tarifa, sem característica, portanto, de tributo, como já ressaltado em acórdão do Supremo Tribunal Federal sobre essa matéria, que salienta a não aplicabilidade ao mesmo dos princípios da legalidade e anterioridade, próprios dos tributos:
"AÇÃO DIRETA DE INCONSTITUCIONALIDADE. DECRETO N. 34.417, DE 24.7.92, DO GOVERNADOR DO ESTADO DO RIO GRANDE DO SUL, QUE INSTITUI E AUTORIZA A COBRANÇA DE PEDÁGIO EM RODOVIA ESTADUAL. ALEGADA AFRONTA AOS PRINCÍPIOS DA LEGALIDADE E DA ANTERIORIDADE.

Tudo está a indicar, entretanto, que se configura, no caso, mero preço público, não sujeito aos princípios invocados, carecendo de plausibilidade, por isso, a tese da inconstitucionalidade. De outra parte, não há falar-se em periculum in mora, já que, se risco de dano existe no pagar o pedágio, o mesmo acontece, na frustração de seu recebimento. com a diferença, apenas, de que, na primeira hipótese, não é ele de todo irreparável, como ocorre na segunda. Cautelar indeferida". 4

36. Cumpre trazer à colação, ainda, acórdão da lavra do Min. José Delgado, do Superior Tribunal de Justiça, através do qual depreende-se claramente que o pedágio se enquadra na categoria de preço público, uma vez que somente é devido pelo usuário quando este faz uso da rodovia. Esclarece o eminente magistrado que:

"A taxa, sim, é impositiva e, mesmo que se refira a serviços divisíceis, não corresponde necessariamente à efetiva proporcionalidade de sua utilização, é como ocorre com a taxa de conservação de estradas de rodagem, que o sujeito passivo está obrigado ao pagamen-

1 BANDEIRA DE MELlo. Celso Antonio. in Parecer publicado na Coletânea de Decisões e Pareceres Jurídicos Sobre Pedágio da Associação Brasileira de Concessionárias de Rodovias - ABCR, São Paulo, 2002, p. 17.

2 TRF/1 R., AMS n ${ }^{\circ}$ 114.328-8-MG, Rel. Juíza Eliana Calmon. DJ 10.06.9l, p. 13.160: TRF/5a R., AMS n ${ }^{\circ}$ 501.291-0-RN, Rel. Juiz José Delgado. DJ 21.09.90.

3 RE n' 181.475-RS. Min. Carlos Velloso. Revista Trimestral de Jurisprudência, Brasília, n. 169, p. 1044-1054, set. 1999, também nesse sentido: Acórdão da $4^{2}$ Câmara de Direito Público do TJSP na AC n. 092.794.5/9-00 (maio de 2000), In: Decisōes e Pareceres Jurídicos sobre o Pedágio, publicaçāo da ABCR - Associação Brasileira da Concessionarias de Rodovias, São Paulo, 2002, p. 47 e segs.

4 ADIMC-800/RS; Ação Direta de Inconstitucionalidade - Medida Cautelar: Relator Min. Ilmar Galvāo; Julgamento: 26.11.1992 Tribunal Pleno, Revista Trimestral de Jurisprudência, Brasília, n. 145, p. 150-154, jul. 1993.

Cabe notar, outrossim, que a referida decisão. nos termos do parágrafo único do artigo 28 da Lei $\mathrm{n}^{\circ}$ 9.868/99 "têm eficácia contra todos e efeito vinculante em relação aos órgãos do Poder Judiciário à Administraçāo Pública federal, estadual e municipal." 
to, quer faça uso ou não da estrada que, efetiva ou potencialmente, serve sua propriedade. E pagará sempre em função de um cálculo que, certamente, não levará em conta a quantidade de vezes em que usar a estrada, mesmo porque, como já dito, pode até nem usá-la. 'Nào é o que ocorre, por exemplo, com o pagamento do transporte público, ao qual está obrigado apenas o usuário do referido transporte, se e quando ele o utilizar, pagando exatamente pela quantidade de vezes em que o usar. Aqui, a contraprestação é tarifa, ou seja, preço publico'." (grifamos)

37. Também o Tribunal Regional Federal da $4^{*}$ e o da $2^{*}$ Regiões expressaram seu entendimento no sentido de que o pedágio, pago pelos usuários em contrapartida ao uso da rodovia concedida, é tarifa, como se ilustra com a reprodução de ementas dos seguintes julgados:

"ADMINISTRATIVO. MANDADO DE SEGURANÇA. PEDÁGIO. TARIFA OU TAXA. PLUS EMBUTIDO NO VALOR DESTINADO AO CUSTEIO DA DUPLICAÇÃO DA RO. DOVIA. LEGITIMIDADE. I. O pedágio não se caracteriza como tributo. seja na modalidade de taxa, imposto ou contribuição de melhoria. Trata-se de tarifa, tem natureza de contraprestação contratual e visa remunerar o serviço público prestado pelas empresas concessionárias, trazendo embutida, inclusive, uma certa margem de lucro em seu valor. 2. Afigura-se legítima a cobrança de um plus embutido no valor do pedágio, destinado ao custeio da duplicação das rodovias, na medida em que a duplicação, diante do volume cada vez maior de veículos em nossas estradas, se insere no conceito de conservação e manutenção das estradas. "2

" SELO-PEDÁGIO. COBRANÇA. CONSTITUCIONALIDADE. I - O poder público não pode estabelecer limitações ao tráfego interestadual e intermunicipal através de tri- buto, mas poderá fazê-lo, através de pedágio, que possui a natureza jurídica de preço público e só será exigido daquele que efetivamente se utilizar do serviço. Sendo o pedágio um preço público, está a salvo da incidência dos limites ao poder de tributar insertos na Constituição Federal, sendo legítima sua cobrança. II - Recurso improvido, para manter a sentença." 3

38. Considerando-se ultrapassado o argumento referente ao enquadramento do pedágio como tributo (taxa) e reconhecendo-se que se trata de tarifa ou preço público, três outros aspectos constitucionais podem ser suscitados. Embora todos levem a reconhecer a constitucionalidade do pedágio, independentemente da existência de via alternativa, é oportuno examiná-los para chegar a essa conclusão. Trataremos, pois, sucessivamente, da liberdade de locomoção, das barreiras interestaduais e da política tarifária.

\section{Do Direito Constitucional de Ir e Vir}

39. A garantia da liberdade de locomoção está prevista no Título II da Constituição Federal, dentre os denominados "direitos e garantias fundamentais":

"Art. 5". (...)

$X V$ - é livre a locomoção no território nacional em tempo de paz, podendo qualquer pessoa, 'nos termos da lei', nele entrar, permanecer ou dele sair com seus bens;

LXVIII - conceder-se-á 'habeas-corpus' sempre que alguém sofrer ou se achar ameaçado de sofrer violência ou coação em sua liberdade de locomoção, por ilegalidade ou abuso de poder";

40. Trata-se de norma constitucional de eficácia contida ${ }^{4}$, uma vez que o enunciado do

\section{STJ, RESp n ${ }^{\circ} 431121 / S P$, j. 07.10.02.}

2 TRF $-4^{2}$ Região, Apelação nº 200004011430400 , Terceira Turma. Relator Juiz Francisco Donizete Gomes, j. 26.11.02.

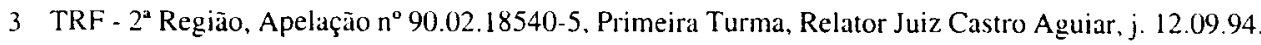

4 Para o enquadramento das normas constitucionais nesta classificação acima, confira-se José Alonso da SILVA: "A Constituição é expressa sobre o assunto quando estatui que as normas definidoras dos 
dispositivo expressamente remete a adaptação do seu conteúdo à lei, ou seja, impõe, como requisito essencial, a intervenção do legislador para a definição do direito assegurado.

41. Cabe salientar, inicialmente, que o direito à locomoção ou direito de ir e vir não se confunde com o de ser garantido a todo cidadão um acesso gratuito à estrada. O primeiro é direito individual de caráter político decorrente da garantia da liberdade individual. O segundo é o direito patrimonial a um serviço público que incumbe ao Estado que pode prestá-lo direta ou indiretamente, gratuita ou onerosamente.

42. O direito de ir e vir tem a proteção do habeas-corpus, e o de utilizar gratuita ou onerosamente as estradas públicas é matéria de direito administrativo que é discutida em ações cíveis próprias.

43. É o que assinalava ainda recentemente o Ministro Sydney Sanches ao encerrar Seminário Jurídico referente às concessões, nos seguintes termos:

"Direito de ir e vir. Eu diria de ir e vir ficar. Para mim não é pedágio é rodágio, mas nunca tinha me ocorrido que alguém pudesse alegar que isso era cerceamento à liberdade de dirigir. Fiquei imaginando que até trabalhar cerceia o direito de liberdade, porque a pessoa pode não querer trabalhar. E ainda com horários ...

O Supremo não tem admitido habeas corpus contra condenações criminais e multa, porque a multa não cerceia liberdade. Antigamente a multa poderia ser revertida em sanção privativa de liberdade se não fosse paga, hoje não mais

Há condenaçōes na área militar em que o cidadão perde o posto ou a patente e impetra habeas corpus para ser mantido no posto ou na patente. mas o Supremo não tem admitido habeas corpus porque não há cerceamento à liberdade de ir e vir. Mesmo se há ameaça de revogação do subsídio, não é motivo para o cidadão pedir, em habeas corpus, o desfazimento da condenação."

44. É, pois, evidente que a extensão do direito de liberdade de ir e vir, assegurado constitucionalmente, é delimitada pela legislação ordinária. Em consequiência, a configuração de violação ao direito de ir e vir, com suporte no preceito constitucional, depende da análise das normas legais pertinentes à matéria.

45. Será demonstrado, no tópico seguinte, que a cobrança do pedágio - mesmo sem a existência de via alternativa gratuita - não implica em violação ao direito de locomoção assegurado na Constituição, na medida em que está plenamente alicerçada em expressas disposições legais.

46. A melhor doutrina esclarece bem que o direito de locomoção, garantido pelo habeas. corpus, não tem como corolário o dever do Estado de prover estradas sem qualquer remuneração.

47. Neste sentido esclarece a juíza Luiza Dias Cassales que:

"Mesmo que a Constituição Federal de 1988 não tivesse estabelecido a limitação do direito de ir e vir aos termos da lei, não seria ele absoluto. Sempre existiram limitações à

direitos e garantias fundamentais têm aplicação imediata. Mas certo é que isso não resolve todas as questōes, porque a Constituição mesma filz depender de legislação ulterior a aplicabilidade de algumas normas definidoras de direitos sociais, enquadrados dentre os fundamentais. Por regra, as normas que consubstanciaram os direitos fundamentais democráticos e individuais são de eficácia contida e aplicabilidade imediata, enquanto as que defïnem os direitos econômicos e sociais tendem a sê-lo também na Constituição vigente, mas algumats, especialmente as que mencionam uma lei integradora, são de eficácia limitada, de princípios programáticos e de aplicabilidade indireta, mas sāo tão jurídicas como as outras e exercem relevante função, porque, quanto mais se aperfeiçoam e adquirem eficácia mais ampla, mais se tomam garantias da democracia e do efetivo exercício dos demais direitos fundamentais". Curso de Direito Constitucional Positivo, 8. ed., Malheiros, São Paulo.

1 Discurso de encerramento do Ministro Sydney Sanches no Seminário Jurídico Concessōes de Serviços Públicos realizado em 08 e 09.06.2001 em Foz do Iguaçu publicado nos respectivos Anais p. 199. 
livre circulação. limitaçôes essas decorrentes da própria convivencia social. Por exemplo qualquer pessoa pode, atili-ando sua liberdade de ir e vir, circular pelas ruas, praças e demais logradouras páblicos. Essa regra geral não é absoluta, visto que comporta exceções. As pessoas só podem circular vestidas. Caso pretendam exercer sua liberdade de ir e vir sem roupas, serão presas por atentado violento ao pudor. Poderão esses individuos, amparados pela garantia de livre circulação, exigir que o Estado the forneça roupas?' A resposta a essa indagação, pondo-se de lado a problemática dos excluídos sociais, só poderá ser negativa. Da mesma forma, quem quiser circular pelas estradas do país é livre para fazê-lo, mas, se utilizar condução coletiva, terá que pagar o preço da passagem, ou. se quiser circular em véiculo próprio ou arrendado, terá que pagar o preşo do véciculo. o de sua conservaçáo, o do combustivel e, se se tratar de veículo arrendado, o preço do aluguel, além do pedágio. Todos esses ônus que incidem sobre quem pretende circular pelas rodovias nacionais ofendem a liberdade de ir e vir?' Certamente que não, visto que são consequiências do próprio progresso e do conforto que dele emana. Não podemos esquecer que o conforto tem seu custo, que, em geral, é alto. Ou por outra, mesmo quando não havia estradas e a locomoģa a pontos mais distantes se fazia utilizando-se cavalos ou carroças, esse trânsito não era gratuito, uma vez que a manutenção dos cavalos e das carroças tinha o seu preço. Com o pedágio, como ensinam Luiz Guilherme Marinoni e Carlos Gustavo Adrioli não se está a impedir ninguém de se dirigir ao lugar que bem entenda. Com ele não está o Estado a limitar esse deslocamento a quaisquer autorizações específicas. Apenas estabelece am condicionamento à utilização de um bèm público. De mais a mais, essa limitação decorre da lei e a locução 'nos termos da lei' 'nāo implica a vedação ou restrição à garantia constitucional, mas apenas o direito do Poder Público a regular".
48. E conclui a ilustre magistrada afirmando que:

"O Direito à liberdade de ir e vir, garantido pelo inciso $X V$ do art. $5^{\circ}$ da Constituição Federal de 1988 não é absoluto, visto que está limitado pelas normas de convivência social e, nos termos do dispositivo constitucional em referência, poderá ser limitado por lei. Como o ir e vir é inerente aos seres mais desenvolvidos da escala biológica, faz parte essencial da natureza humana e suas restrições devem limitar-se às necessidades do convívio em sociedade e à expansão das vantagens, quer de ordem econômica, quer de conforto, trazidas pelo progresso tecnológico. O pedágio, que tem suas raizes, provavelmente, no Império Romano, por ser exigido apenas dos usuários das rodovias, não pode ser qualificado como taxa, sendo sua natureza a de tarifa ou preço público. Consoante legislação vigente para que seja exigido pedágio, não há necessidade de rodovia altemativa gratuita." ?

49. Por sua vez, o Professor Marçal JUSTEN esclarece que:

"Parece claro que a idéia de que uma exigência econômica para fruição de serviço público caracterizaria violação a garantias constitucionais não pode ser levada às últimas conseqüencias. Aplicar o raciocínio em termos genéricos e amplos produziria resultados inadmissiveis. Porque eu teria de supor que, se todo serviço público devesse ser pres. tado gratuitamente, toda a contrapartida pela prestação do serviço público envolveria uma infração à Constituição. Isso se passaria não apenas no tocante ao tema de rodovias. Ora, todo o elenco de serviços públicos prestados pelo Estado comporta a cobrança de uma remuneração, ressalvadas apenas as hipóteses em que constitucionalmente se assegura a gratuidade, como se passa, por exemplo, com o ensino fundamental, com o acesso a saúde etc.

Fora das garantias constitucionais à gratuidade, é ponto pacífico a possibilidade da cobrança pela prestação de serviço público. Ou

1 Ob. cit., na nota anterior, p. 179.

2 Ob. cit. na nota anterior, p. 182. 
seja, em última análise nós teríamos de supor que o raciocínio ora examinado, levado às últimas consequiências, significaria o fím do serviço público remunerado, não gratuito. Todo serviço público teria de ser remunerado." 1

50. E complementa o seu pensamento ao afirmar que:

" $O$ direito de ir e vir consiste, em láltima análise, em limitação ao poder estatal de constranger ou restringir o deslocamento fisico do sujeito ao longo de um espaço geográfico de propriedade pública e de uso não exclusivo do Estado.

Mas isso, o direito de ir e vir, não gera nenhum dever de atuação ativa do Estado. $O$ direito de ir e vir, por sua natureza, impõe a abstenção do Estado, como disse a carissima Doutora Luiza, não gera o dever de o Estado fornecer nem o combustivel, nem o sapato, não gera o dever do Estado atuar ativamente. O Estado preenche, satisfaz o requisito fundamental do direito constitucional quando ele simplesmente se abstém de atuar.

Logo, nós podemos supor que o particular pode invocar o direito de ir e vir em face do Estado para impedir que ele estabeleça obstáculos ou impedimentos ao deslocamento. Mas, não é possível que seja invocado o direito de ir e vir para obstaculizar a prestação do serviço público, que se submete a um outro regime jurídico constitucional, o qual admite cobrança e remuneração pelos custos correspondentes à prestação da utilidade." 2

\section{A LIBERDADE DE LOCOMOÇÃO E AS LIMITAÇÕES AO DIREITO DE TRIBUTAR}

51. Ainda sobre a liberdade de locomoção. tratando das limitações constitucionais ao poder de tributar, a Carta Magna prevê:
"Art. 150. Sem prejuizo de outras garantias asseguradas ao contribuinte, é vedado à União, aos Estados, ao Distrito Federal e aos Municípios:

(...)

$V$ - estabelecer limitações ao tráfego de pessoas ou bens, por meio de tributos interestaduais ou intermunicipais, ressalvada a cobrança de pedágio pela utilização de vias conservadas pelo Poder Público."

52. A doutrina, comentando o texto constitucional, tem salientado que:

"Este inciso cuidou apenas de barreiras tributárias. que me parecem de difícil configuração, à luz do sistema vigente, mesmo no concernente ao ICMS, posto que as alíquotas interestaduais são definidas obrigatoriamente pelo Senado Federal."3 (grifamos)

53. Para Hely Lopes MEIRELLES, trata-se de um equívoco de técnica, como salientou quando falava da Constituição de 1967:

"Esse êrro de técnica passou para a Constituição do Brasil de 1967, que no inciso II do art. 20, repetiu a mesma impropriedade, ao vedar a cobrança de tributos interestaduais ou intermunicipais, exceto o pedágio para atender ao custo de vias de transporte. Ora, se o pedágio não é tributo (é preço), não tinha que ser excetuado dos tributos, porque já não estava alcançado pela vedação constitucional. Sua cobrança seria permitida, independentemente da ressalva oposta pelo desavisado constituinte. Nenhum preço exige permissão constitucional para ser cobrado. Todos êles decorrem do poder genérico concedido à União, aos Estados e aos Municípios - e seus delegados: concessionários e permissionários - de haver a remuneração de seus bens e serviços." ${ }^{4}$

54. A referência que o artigo fez ao pedágio só se explica como explicitação do direito do Estado de cobrar o pedágio que, no passado,

1 Ob. cit. na nota anterior, p. 185.

2 Ob. cit. na nota anterior, p. 186/187.

3 Celso Ribeiro BASTOS e Ives Gandra MARTINS, Comentários à Constituição do Brasil. v. 6, Saraiva, 1990. p. 168

4 Helly Lopes MEIRELLES, Estudos e Pareceres de Direito Público, Revista dos Tribunais, 1971, p. 328. 
foi, algumas vezes, considerado como taxa. $O$ que o constituinte pretendeu dizer foi que o pedágio é um instrumento lícito utilizável pelo Poder Público, quer seja considerado como preço público ou como taxal.

55. A vedação contida no texto constitucional deve ser entendida como constituindo a proibição da incidencia de tributo, gravando a circulação de pessoas e de bens. De fato, as pessoas têm livre trânsito em todo o território nacional. sem o pagamento de tributo de qualquer natureza, para entrar ou sair de qualquer zona ou ponto. Impostos e taxas não podem gravar a circulação de pessoas'.

56. A cobrança do pedágio. entretanto, não pode ser enquadrada como imposição tributária. Por outro lado, é inadmissível que se entenda que a Constituição de 1988 ressalve a cobrança de pedágio nos casos em que este seja tributo, mas não autorize a sua cobrança nos casos en que este seja tarifa. Ora, se o pedágio pode ser cobrado nos casos em que se caracteriza como tributo. com maior razão o pode nos casos en que se caracteriza como tarifa? ${ }^{2}$.

57. Na verdade, a exegese do artigo $150, \mathrm{~V}$ deve ser sistematizada com as disposições do art. 175, ambos da Constituição Federal, que versam sobre a concessão de serviço público, deixando expresso que o serviço prestado mediante outorga da concessão é remunerado mediante "tarifa".

\section{O PEDÁGIO E A POLÍTICA TARIFÁRIA}

58. O art. 175 da Constituição tem a seguinte redação:

"Art. 175. Incumbe ao Poder Páblico, na forma da lei, diretamente ou sob regime de concessão ou permissão. sempre atrav'és de licitação, a prestação de serviços públicos.
Parágrafo único. A lei disporá sobre:

I - o regime das empresas concessionárias e permissionárias de serviços públicos, o caráter especial de seu contrato e de sua prorrogaçăo, bem como as condições de caducidade, fiscalização e rescisão da concessão ou permissão:

II - os direitos dos usuários:

III - política tarifária;

IV - a obrigação de manter serviço adequado",

59. Regulamentando a previsão constitucional, foi editada a Lei $n^{\circ} 8.987$, de 13 de fevereiro de 1995. que no seu art. $1^{\circ}$ dispõe:

"Art. 1". As concessões de serviços públicos e de obras públicas e as permissões de serviços públicos reger-se-ão pelos termos do art 175 da Constituição Federal, por esta Lei. pelas normas legais pertinentes e pelas cláusulas dos indispensáveis contratos."

60. No seu art $2^{\circ}$, enuncia e define as espécies de concessão de serviço público, estabelecendo que a remuneração pelo serviço concedido é feita mediante o pagamento de tarifa pelos respectivos usuários:

"Art. 2". Para os fins do disposto nesta Lei, consideram-se:

II. concessão de serviço público: a delegação de sua prestação, feita pelo Poder Concedente, mediante licitação, na modalidade de concorrência, à pessoa jurídica ou consórcio de empresas que demonstre capacidade para seu desempenho, por sua conta e risco e por prazo determinado;

III. concessão de serviço público precedida da execução de obra pública: a construção. total ou parcial, conservação, reforma, ampliação ou melhoramento de quaisquer obras de interesse público, delegada pelo Poder Concedente, mediante licitação, na modalidade de concorrência, à pessoa jurídica ou consórcio de empresas que demonstre capacidade para a sua realização, por sua conta e risco. de forma que o investimento da concessionária seja remunerado e amortizado mediante a

I J. CRETELLA JÚNIOR. Comentários à Constimição 1998, VII. Forense Universitária. 1992, 1ª ed., p. 3554.

2 Antônio Carlos Cintra do AMARAL, monografia editada por seminários CELC, fev. 1997, p. 26. 
exploração do serviço ou da obra por prazo determinado;"

61. Com a edição da Lei $n^{\circ} 9.074$, de 07 de julho de 1995, foi claramente determinado que as vias federais. precedidas ou não da execução de obra pública, sujeitam-se ao regime de concessão previsto na Lei $n^{\circ}$ 8.887/95:

"Art. l". Sujeitam-se ao regime de concessão ou, quando couber, de permissão, nos termos da Lei $n^{\circ} 8.987$, de 13 de fevereiro de 1995, os seguintes serviços e obras públicas de competência da União:

I. (VETADO);

II. (VETADO);

III. (VETADO);

IV. vias federais, precedidas ou não da execução de obra pública:"

62. Já salientamos a respeito que:

"Estão enunciadas, em caráter exaustivo, no art. $I^{\circ}$ da Lei $n^{\circ} 9.074 / 95$, as atividades econômicas que podem estar submetidas ao regime de concessão e permissão de serviços públicos, além das já previstas na Constituição Federal, nos Estados, nas Leis Orgânicas Municipais, e em legislação específica".

"Objetivou a lei geral estabelecer quais os serviços, enquadráveis na categoria doutrinária de serviços de utilidade pública, passíveis de delegação pelo Poder Público à iniciativa privada, deixando claro, no art. $2^{\circ}$, que está vedada a ampliação das hipóteses de delegação, salvo se houver previsão constitucional ou legal, sendo que, tratando-se de lei, devem ser delimitados os termos e condicionamentos da outorga de concessão ou permissão, proibição esta que se estende aos Estados e Municípios, no âmbito do regime constitucional de repartição de competências em matéria de serviços públicos!."

63. Cabe frisar que a questão da aplicação ou não do disposto no art. 150 . V, da Constituição Federal, ligada à natureza jurídica do pedágio, foi amplamente debatida quando da edição da Lei $n^{\circ} 7.712$, de 22.12.88, que disciplinava a cobrança de pedágio nas rodovias federais.

64. Naquela ocasião, a Procuradoria da Fazenda Nacional, manifestando-se sobre o assunto, em especial quanto ao contido no art. 150 , inciso $V$, da Constituição Federal, firmou o seguinte entendimento:

"O princípio constitucional previsto no art. 150, inciso $V$, decorre do conceito de unidade do território do país, pelo que não se pode. por meio de imposição tributária, impedir ou restringir a circulação de pessoas ou bens em todo o território nacional. No entanto, a cobrança do pedágio em qualquer via de transportes é, sem dúvida alguma, constitucional, mesmo que estivesse a natureza tributária. uma vez que a ressalva prevista no art. 150 , $V$, da $C F$, apresenta-se inteiramente inútil. por não incidir pedágio sobre o tráfego em si mesmo, que é o objeto da proibição constitucional, e nem constituir espécie de tributo interestadual ou intermunicipal. O pedágio visa tão-somente atender ao custo de conservação e melhoramentos das vias de transportes, e o que se veda é a utilização de tributo que represente uma barreira ao tráfego interestadual ou intermunicipal."

65. Sobre o tema, também se posicionou, à época, a Procuradoria Geral da República, nos seguintes termos:

"O pedágio, na hipótese dos autos, é devido pela utilização de bens públicos - rodovias federais, pontes e demais obras de arte nelas existentes. Não se trata de contraprestaçāo de um serviço público, nem do exercício do poder de polícia, mas de execução de obra pública.

Assim, não é taxa, mas preço, como também é. por exemplo, a contraprestação paga pelo usuário de imóvel do Domínio público (em que pese a equivocada denominação de taxa, que, por vezes, lhe é dada - taxa de

1 Amoldo WALD, Luiza Rangel de MORAES e Alexandre de Mendonça WALD, $O$ Direito de Parceira e a Nova Lei de Concessöes, Revista dos Tribunais, 1996, ps. 175/176.

2 Parecer PGNF/CDFN/No 214/89, de 03.04.89 - ANEOR - OUTUBRO/89 - p. l-1 e segs. 
ocupação), competindo à entidade titular do bem fixar-lhe o valor fundada em critérios que julgar mais adequados, respeitados eventuais parâmetros legais (no caso, os do art. $3^{\circ}$ da Lei)." (op. cit. p.J-1)

\section{DA ANÁLISE DA LEGISLAÇÃO ORDINÁRIA - INEXISTÊNCIA DE LEI QUE CONDICIONE A COBRANÇA DE PEDÁGIO À POSSIBILIDADE DE UTILIZAÇÃO DE VIA ALTERNATIVA}

66. Conforme já demonstrado no presente estudo, a lei ordinária autoriza expressamente a cobrança de pedágio pelas concessionárias de obra pública, consistindo a referida tarifa em remuneração do serviço prestado pelo particular. en nome do Estado.

67. Por outro lado, não há. no sistema jurídico brasileiro, qualquer dispositivo legal que condicione tal cobrança à existência de via alternativa gratuita de trânsito.

68. Ao contrário, a Lei de Concessões, em seu art. $9^{\circ}, \$ 1^{\circ}$, expressamente exclui a exigência de disponibilização de serviço alternativo para a cobrança de tarifa pelo concessionário, salvo nas exceções nela mesma previstas, nos seguintes têrmos:

" \$ $1^{\circ}$ A tarifa não será subordinada à le. gislação especifica anterior e somente nos casos expressamente previstos em lei, sua cobrança poderá ser condicionada à existência de serviço publico alternativo e gratuito para o usuário."

69. Lembre-se, ainda, que en nosso sistema jurídico as disposições constitucionais devem ser sempre interpretadas sistematicamente e atendendo à fïnalidade a que se dirigem, sendo certo que a falta desta elementar orientação hermenêutica pode causar graves equívocos, conferindo sentido distinto daquele que o constituinte pretendeu atribuir às normas.

70. Aplica-se, na exegese, ainda, outro dispositivo constitucional, qual seja o art. $5^{\circ}$, II, da Constituição Federal de 1988, segundo o qual "ninguém é obrigado a fazer ou deixar de fazer alguma coisa senaio em virtude de lei"

71. Ora, se. no caso em espécie. a lei autoriza expressamente o concessionírio a cobrar o pedágio e não condiciona tal cobrança à existência de via alternativa gratuita de trânsito, não poderia ser outra a interpretaçãa dada ao art. $5^{\circ}$. XV. da Constituição Federal, senão a de que a cobrança de pedágio independentemente da existência de via alternativa conforma-se perfeitamente com o direito constitucional de liberdade de locomoção.

72. Note-se, pois, que se o usuário optar por fazer uso do serviço, deverá pagar o seu preço. assim como o faz quando se utiliza de qualquer serviço público prestado por particular. É assim com o serviço de telefonia, eletricidade, transporte etc.

73. Portanto, são três as premissas que nos fazem concluir pela absoluta legalidade e constitucionatidade da cobrança de pedágio. independentemente da existência de via alternativa:

- Primeira premissa: o direito de liberdade de locomoção do usuário, direito político de ir e vir, é norma de eficácia contida, ou seja, tem seus limites fixados pela lei;

- Segunda premissa: a lei exclui a exigência de disponibilização de serviço alternativo para a cobrança de tarifa pelo concessionário, salvo nas exceções nela mesma previstas: $c$

- Terceira premissa: não há lei alguma que obrigue o concessionário a disponibilizar via alternativa de trânsito para a cobrança da tarifa devida em virtude da prestação do seu serviço. Não só a Constituição determina que ninguém é obrigado a fazer ou deixar de fazer alguma coisa senão en virtude de lei (CF, art. $5^{\circ}$, II). como, ainda, a política tarifária e o regime das contratações públicas constitucionalmente previstos (CF, art. 175 e 37, XXI) pressupõem a remuneração das empresas concessionárias por tarifas que thes assegurem o equilibrio econômico e financeiro, conforme tem entendido o Supremo Tribunal Federal.

VIII. DA LIBERDADE DE ESCOLHA DOS USUÁRIOS CONSAGRADA NA LEI DE CONCESSÕES - GARANTIA DO DIREITO DE ESCOLHA ENTRE OS SERVIÇOS DOS VÁRIOS CONCESSIONÁRIOS E NÃO ENTRE SERVIÇOS PAGOS E SERVIÇOS ALTERNATIVOS GRATUITOS 
74. Ultrapassadas as questões atinentes ao direito constitucional, passamos a analisar apenas para que não restem dúvidas sobre a legalidade da cobrança de pedágio independentemente da existência de via alternativa - o direito de liberdade de escolha dos usuários consagrado no art. $7^{\circ}$ da Lei de Concessōes, verbis:

"Art. $7^{\circ}$. Sem prejuízo do disposto na Lei $n^{\circ}$ 8.078, de 11 de setembro de 1990, são direitos e obrigações dos usuários:

(...)

III - obter e utilizar o serviço, com liberdade de escolha 'entre vários prestadores de serviços, quando for o caso', observadas as normas do poder concedente; " (o trecho grifado foi acrescentado pela Lei $n^{\circ} 9.648$, de 27.05.98)

75. A redação do referido dispositivo legal antes da edição da Lei $n^{\circ} 9.648 / 98$ - que acrescentou o trecho "entre vários prestadores de serviços público, quando for o caso" - deixava dúvidas a respeito da exata extensão conferida pelo legislador ao termo "liberdade de escolha".

76. Chegou-se a sustentar, numa interpretação totalmente absurda, que o direito de liberdade de escolha do usuário referir-se-ia à escolha entre a utilização de serviço oneroso e de serviço gratuito, o que, no caso de concessão de rodovias, implicaria a necessidade de disponibilizar ao usuário uma via de trânsito gratuita, além daquela em que a utilização é condicionada a pagamento do pedágio.

77. Não é esta, contudo, a interpretação consistente com o ordenamento jurídico da matéria. A alternativa que se abre é escolher entre utilizar o serviço público de um ou de outro concessionário, quando for o caso, e pagando a respectiva tarifa, o que. aliás, ficou mais claro e evidente com a redação dada ao art. $7^{\circ}$, III, pela Lei $n^{\circ} 9.648 / 98$.
78. Efetivamente, se a lei se referisse à liberdade de escolha entre a utilização da rodovia mediante o pagamento de pedágio e a utilização da estrada gratuita. ter-se-ia que entender que. para cobrar tarifa para a prestação de qualquer serviço público. dever-se-ia disponibilizar uma alternativa para o usuário. uma vez que a lei não faz distinção entre a concessão de serviço público e de obra pública. Não é isso o que ocorre, entretanto. com os serviços públicos de telecomunicações, água, esgoto, energia ou gás canalizado, por exemplo'.

79. Note-se, pois, que se o usuário optar por fazer uso do serviço, deverá pagar o seu preço, assim como o faz quando se utiliza de qualquer serviço público prestado por particular. É assin com o serviço de telefonia, eletricidade, transporte. etc. É assim. também, com o acesso a museus. e jamais se cogitou qualquer violação ao direito à educação, assegurado pelo art. $6^{\circ}$, caput, da Constituição $\mathrm{Fe}$ deral.

80. Finalmente, qualquer controvérsia a respeito da interpretação do termo "liberdade de escolha" foi dirimida pela Lei ${ }^{0} 9.648 / 98$, que deixou claro que a liberdade de escolha tratada no aludido dispositivo está relacionada à não-exclusividade da outorga da concessão, imposta no art. 16 da Lei de Concessões². Daí se conclui que o direito à liberdade de escolha assegurado ao usuário na Lei de Concessões nada tem a ver com a exigência de disponibilização de via de trânsito alternativa gratuita, mas sim com a livre competição entre os concessionários, quando for o caso.

81. Cumpre considerar, ainda, embora tal questão não seja relevante para o presente estudo, que o acréscimo da expressão "quando for o caso" ao referido dispositivo não ocorreu ocasionalmente, sendo certo que a liberdade de escolha do usuário está restrita aos casos em que for viável técnica e econo-

I Antônio Carlos Cintra do AMARAL. Concessão de rodovias e cobrança de pedágio, art. publicado no livro Decisões e Pareceres Jurídicos sobre Pedágio - Associação Brasileira de Concessionárias de Rodovias - ABCR, p. $21 / 33$.

2 "Art. 16. A outorga de concessão ou permissão não terá caráter de exclusividade, salvo no caso de inviabilidade técnica ou econômica justificada no ato a que se refere o art. $5^{\circ}$ desta Lei." 
micamente a outorga da concessão a mais de um prestador do serviço, sob o regime de liberdade de competição.

82. Tal garantia não se aplica, portanto, ao caso de concessão de rodovia. devido à própria natureza do serviço concedido, uma vez que, ao contrário do que ocorre com os serviços de telecomunicações. por exemplo, nos quais pode ser perfeitamente viável a exploração da mesma área por diversas operadoras de telefonia. é inconcebivel a exploração de um mesmo trecho por mais de uma concessionária.

\section{DA EVOLUÇÃO DO POSICIONAMENTO DOUTRINÁRIO E JURISPRUDENCIAL}

\section{A) A Doutrina}

83. Conforme já salientamos, o $§ 1^{\circ}$, do art. $9^{\circ}$, da Lei de Concessões exclui expressamente a exigência de disponibilização de serviço alternativo para a cobrança de tarifa pelo concessionário. Assim, após a promulgação da legislação sobre concessões, a desnecessidade de existência de via alternativa para a cobrança de pedágio pelo concessionário tornou-se evidente ex vi legis.

84. Importante esclarecer, aqui, que quando houve a cobrança de pedágio pela DERSA, em 1969, demos parecer, simultaneamente com mestres de direito administrativo como Pontes de MIRANDA, Seabra FAGUNDES e Hely Lopes MEIRELLES, afirmando a conveniência de haver rotas alternativas para a cobrança de pedágio.'

85. O mesmo entendimento tiveram, na ocasião, Hely Lopes MEIRELLES² e Orlando Carlos GANDOLFO, então Procurador do Estado de São Paulo ${ }^{3}$.
86. Naquela época, deixamos claro que nossas conclusões não tiveram fundamento na letra da lei - uma vez que os textos legais referentes ao pedágio não faziam nenhuma referência à necessidade de via alternativa mas se ampararam em algumas legislações estrangeiras de países industrializados em que já existia ampla rede de estradas e que se encontravam em nível de desenvolvimento mais adiantado do que o nosso.

87. Pautamo-nos, especialmente, nas lições de Assis Ribeiro, o qual esclareceu que o público americano aceitou o princípio de que no custo de transporte inclui-se, também, o custo da estrada, partindo da premissa da opção entre a auto-estrada paga e a estrada tradicional gratuita ${ }^{4}$.

88. É preciso entender que, por ocasião da referida manifestaçāo, em 1969, inexistia praticamente legislação sobre concessões no Brasil em matéria de estradas de rodagem e as próprias concessões que se fizeram na época eram dadas a empresas públicas ou sociedades de economia mista como foi o caso da DERSA - Desenvolvimento Rodoviários S.A., criada pelo Decreto-lei $n^{\circ} 5$, de 06.03.1969. Foi para a mencionada empresa que foram dados os pareceres e a função por ela desempenhada se limitava, na época, à construção da Via Anchieta e da Rodovia dos Imigrantes, em relação às quais existiam vias alternativas. Diante das dúvidas então existentes, a própria DERSA colocou como premissa para a sua consulta a existência de via alternativa, o que ensejou as respostas dadas tanto pelo mestre Hely Lopes Meirelles quanto pelo Procurador Orlando Carlos Gandolfo e por mim mesmo.

89. Essia questão acabou sendo decidida pelo Judiciário em 1975, quando do julgamento, pelo Tribunal de Justiça de São Paulo, de recurso de apelaçãos de sentença que julgara improcedente o mandado de segurança

1 Ob. cit. p. 12/13.

2 Hely Lopes MEIRELLES, ob. cit., p. 26.

3 Orlando Carlos GANDOLFO. ob. cit. p. 18.

4 Assis RIBEIRO, Financiamento de Obras Públicas, Rio de Janeiro, Ediçōes Financeiras, 1956, p. 192. 
impetrado contra o Diretor- Presidente da DERSA, sustentando a ilegalidade da exigência do pedágio na Via Anchieta, após a interdição, em 29 de dezembro de 1974, da Estrada Velha, tida como via alternativa daquela. Naquela oportunidade, assim se manifestou a $4^{\mathrm{a}}$ Câmara Civil do Eg. Tribunal de Justiça de São Paulo:

"Improcede, também, a alegação de que a cobrança do pedágio estaria condicionada à prévia existência de alternativa viária desimpedida. O Decreto-lei $n^{\circ} 5 / 1969$, que instituiu a agência impetrada e estabeleceu o pedágio, em nenhum de seus dispositivos condicionou a exigência da cobrança à prévia existência de outra alternativa viária. Assim, eventual interdição da Estrada Velha não poderia implicar a inexibilidade do pedágio."

90. Decorridos quase trinta e cinco anos, mudou substancialmente o Brasil e o direito vigente. As privatizações e as concessões desenvolveram-se, com nova feição, na última década do século passado, transformando-se completamente o quadro legislativo. Tratavase, agora, de concessões a empresas privadas que deviam ser adequadamente remuneradas, numa fase em que o Estado só conseguia combater o déficit público transferindo parte das suas atividades para a iniciativa privada. É o Estado que deixou de ser operador em vários setores para transformar-se em regulador $\mathrm{e}$ fiscal.

91. Assim sendo, em razão da exclusão expressa constante da Lei de Concessões a respeito da exigência de disponibilização de serviço alternativo ao usuário, parece-nos ultrapassado o posicionamento adotado naquela época. Mudando a lei, a doutrina evolui para atender as determinações do direito vigente.
Pois agora legem habermus e é preciso cumprir a lei.

92. $\mathrm{Na}$ doutrina atual, o entendimento pela desnecessidade de existência de via alternativa gratuita para a cobrança de pedágio pela concessionária é predominante.

93. Desde 1996, defendemos o uso amplo do pedágio como instrumento de renovação da nossa infra-estrutura ${ }^{1}$, entendendo que pode haver concessão de estradas de rodagem com ou sem pista dupla ${ }^{2}$, e havendo ou não via alternativa.

94. Posição idêntica é de Eurico de Andrade AZEVEDO e Maria Lúcia Mazzei ALEN$\mathrm{CAR}^{3}$, bem como do Ministro Sydney Sanches, do Professor Marçal Justen Filho e da Juiza Luiza Dias Cassales, que abordaram o assunto em seminário realizado em 2001. ao qual já aludimos.

95. Por sua vez, Luiz Guilherme MARINONI e Carlos Gustavo ADRIOLI, consultados sobre se a cobrança de pedágio, sem que o Poder Público disponibilize uma via alternativa gratuita ao usuário, configuraria violação ao direito constitucional de liberdade de locomocação (CF, art. $5^{\circ}, \mathrm{XV}$ ) e ao direito de livre escolha consagrado no art. $7^{\circ}$, III, da Lei de Concessões, concluem que a cobrança de pedágio sem a existência de via alternativa é constitucional e legal. ${ }^{4}$

96. Esclarecem os juristas que a cobrança de pedágio não é inconstitucional porque o próprio art. $5^{\circ}, \mathrm{XV}$, da $\mathrm{CF}$, "remete a conformação do conteúdo do direito de liberdade de locomoção à lei ordinária", sendo que a Lei de Concessões "admite a cobrança de tarifa pela prestação do serviço ou pela conservação, reforma, ampliação ou melhoria da obra" 5 .

8 TJ/SP, Apelação Cível n 244.842, $4^{\text {a }}$ Câmara Civil, Relator Des. Barbosa Pereira Filho, j. 25.09.75.

1 Arnoldo WALD, Luiza Rangel de MORAES e Alexandre de M. WALD, $O$ direito de parceria já citado $n^{\circ}$ s $5.25,10.34$ e 15, p. 48,90 e 244 e seg.

2 Itens n's 34 a 41 do presente parecer.

3 Eurico de Andrade AZEVEDO e Maria Lúcia Mazzei ALENCAR, Concessão de Serviços Públicos, Comentários às Leis 8.987 e 9.074 (Parte Geral), com as modificações introduzidas pela Lei 9.648, de 27.5.98, São Paulo, Malheiros, 1998, p. 29/30.

4 RT $777 / 119$. 
97. A ilegalidade da cobrança de pedágio sem a disponibilização de via alternativa gratuita também foi rechaçada pelos doutrinadores, em virtude da liberdade de escolha prevista na Lei de Concessōes referir-se à não exclusividade na prestação dos serviços, conforme também já salientamos.

98. E após mencionar o supra transcrito $1^{\circ}$, do art. $9^{\circ}$, da Lei de Concessões. segundo o qual a cobrança de tarifa pelo concessionário não pode ser condicionada à existência de serviço público alternativo gratuito, os aludidos autores concluem:

"... não existindo Lei que expressamente condicione a cobrança de pedágio à existên. cia de uma via gratuita de trânsito, vê-se que a postulação do autor não encontra arrimo no sistema jurídico pátrio."

99. Compartilhando do mesmo entendimento. Orlando Gomes GANDOLFO, quando ainda ocupava o cargo de Procurador Subchefe do Estado de São Paulo em exercício junto à DERSA. esclareceu que:

“... não há lei condicionando a cobrança de pedágio, sob a forma de preço público. à existência de rodovia tradicional de uso gratuito para servir como alternativa ao usuário"?

100. Vale a pena mencionar, ainda, a obra de Luiz Carlos Kal Liamondi MACHADO. na qual foram detalhadamente abordados os aspectos pertinentes à implantação, conservação e operação das rodovias. à luz dos modelos econômicos envolvidos. Diante da situação constatada, de que a legislação federal reguladora das concessões de serviços públicos não estabelece a obrigatoriedade, para o poder público, de manter vias alternativas livres de pedágio como condição prévia para a outorga de concessões para empreendimentos rodoviários, o Autor posiciona as situaçōes que se configuram para desenvolver e dimensionar projetos de concessões de rodovias:

a) a primeira, em que não há vias alternativas livres de pedágio, de uso gratuito;

b) a segunda, em que existem outras vias, para o mesmo trajeto, sem pedágio, competindo diretamente com as vias pedagiadas pela preferência dos usuários.

101. Diz ele, a respeito das duas situações:

"Embora não seja a prática adotada na maioria das concessões de rodovias feitas no Brasil, existem estudos que propõem metodologias para consulta prévia aos usuários. Estes, identificando o nivel de benfeitorias que desejam. escolhem as tarifas que estariam dispostos a pagar. Exemplos nesse sentido estão disponíveis nos trabalhos publicados pelo Lastran, Laboratório de Transportes da UFRGS, sob a coordenação dos profs. Luiz Afonso dos Santos SENNA e Fernando Dutra MICHEL. Também nesse campo, merece destaque a contribuição metodológica do prof. Rutsnei SCHMITZ, da UFSC, de abril de 2001, que permite medir o fluxo de demanda em função do valor da tarifa estabelecido.

No segundo caso, entretanto, por se tratar de projetos de concessões de rodovias em que os usuários contam com vias alternativas competitivas, de uso isento de pedágio, não há sentido prático em o poder concedente interferir no estabelecimento de limitaçós quanto aos valores do pedágio. Cumpridos os preceitos legais pertinentes, verificado e controlado pelo poder concedente o atendimento às disposiçōes de interesse técnico, de ordem sócio-econômica e de ordem estratégica da administração pública, o problema de estabelecimento de valores de tarifas de pedágio passa a ser assunto de preocupação exclusiva das concessionárias." 3

B) A Jurisprudência

8 In op. cit., p. 130 e 132.

1 In op. cit.. p. 136.

2 RDA 122/407.

3 Luiz Carlos Kal Liamondi MACHADO. Concessöes de Rodovias - Mito e Realidade, Campinas SP, Prêmio Editora. 2002, p. 75 e 76. 
102. A jurisprudência dos Tribunais pátrios, após o precedente de 1975, do Tribunal de Justiça de São Paulo, acima citado, tem consolidado o entendimento de que a cobrança de pedágio não está condicionada à existência de via alternativa gratuita de trânsito. É o que se pode verificar pela seguinte decisão:

"Em meu modo de entender, o que o inciso $X V$ do art. $5^{\circ}$ da $C F / 88$ garante é que o indivíduo (não seu automóvel ou caminhão) possa livremente locomover-se no território nacional sem nenhuma limitação de ordem pessoal. Certamente que se resolver locomoverse pelo território nacional de ônibus, de trem ou avião terá que pagar passagem ou bilhetes, se for em seu veículo terá que pagar o seu preço, o preço de sua conservação, do combustivel e o do pedágio." 1

103. Outra decisão digna de nota foi proferida pelo Tribunal de Justiça do Estado do Rio Grande do Sul, deixando claro que a cobrança do pedágio, sem qualquer outra condição (como a de existência de via alternativa) torna mais justa a repartição dos ônus de construção e manutenção das rodovias entre os próprios usuários, e não entre todos os contribuintes. como seria caso este investimento tivesse que ser patrocinado pelo Poder Público via impostos.

"PEDÁGIO (RODÁGIO). RODOVIA. DECRETO. ESPÉCIES DE PEDÁGIOS. SEMELHANÇA E DISTINÇÃO. RODOVIA ALTERNATIVA. DEFINIÇÃOO NO CASO. 1. ESPÉCIES DE PEDÁGIOS (RODÁGIOS).

$$
\text { (omissis)..... }
$$

'2.3. A rodovia alternativa não é imprescindivel ao pedágio-tarifa porque este incide (cobra) apenas pelos serviços de manutenção, que são um dever do poder público. Assim. (a) pagar pela manulenção é um dever do usuário que independe da cobrança de pedágio; $e$ (b) se o poder público não cobrar de quem usa e danifica, terá que fazê-lo de toda a sociedade por meio de impostos'. 3.
Preço e uso proporcional. Eventual inclusão do preço do pedágio-tarifa de rubrica própria do pedágio-taxa, gera direito ao expurgo, e não a redefinição para excluir todo o pagamento, sob pena de restar excluido o dever do usuário, em prejuizo da sociedade como um todo. Não vigora o princípio do preço proporcional à distância percorrida porque ele é previsto segundo o custo dos seriçcos na sua globalidade. 4. Circunstâncias que, no caso concreto, definem a cobrança como pedágio-tarifa, inclusive, como reforço, a existência de rodovia alternativa. 5. Agravo desprovido." = (grifamos)

104. Transcrevemos, ainda, mais dois julgados, dentre outros, que deixam claramente evidenciado o entendimento quanto à desnecessidade da existência de via alternativa gratuita, para que se configure a viabilidade jurídica da exigência do pedágio:

"AÇÃO DECLARATÓRIA. TRIBUTÁRIO. PEDÁGIO-TARIFA. POSSIBILIDADE DE INSTITUIÇÃO POR DECRETO. 'Regime jurídico contratual de exploração, que não está adstrito a existência de rodovia alternativa'. Trata-se de hipótese de pedágio-tarifa, que decorre do poder do Estado de dispor a respeito da organização e funcionamento da ad. ministração (artigo 84, inciso VI, da Constituição Federal), com a correlata atividade estatal especifica em contraprestação (conservação e restauração de rodovia). 'Inexiste. pois, vício de inconstitucionalidade. Tem como fato gerador a efetiva utilização da rodovia e dos serviços públicos específicos; corresponde, exclusivamente, ao uso da via, cujo regime jurídico de exploração é contratual, através de concessionária ou permissionária do poder público. A opção do poder publico pelo regime contratual não está ads. trita à existência de rodovia alternativa, que seria apenas mais um fator da caracterização do pedágio, no caso, como tarifa'. Tarifa não é taxa, não precisa observar os princípios

1 Decisão proferida em 22.09.98 pela então Juíza do TRF da $4^{\mathbf{a}}$ Regiāo Luiza Dias Cassales no AI $n^{\circ}$ 1999.04.01.059950-5.

2 TJ/RS, Agravo de Instrumento $n^{\circ} 598220788$, Primeira Câmara Cível, Relator Des. Irineu Mariani, j. 28.04.99. 
próprios a esta, podendo ser instituída por Decreto. Apelo provido por maioria. Voto vencido."' (grifamos)

“'Improcede, também, a alegação de que a cobrança do pedágio estaria condicionada à prévia existência de alternativa viária desimpedida'. O Decreto-lei $n^{\circ}$ 5/1969, que instituiu a empresa impetrada e estabelecen o pedágio, em nenhum de seus dispositivos condicionou a exigência da cobrança à préria existência de outra alternativa viária. Assim. eventual interdição da Estrada Velha não poderia implicar a inexigibilidade de pedágio." 2 (grifamos)

105. Vê-se, assim, que é predominante o posicionamento doutrinário e jurisprudencial pela desnecessidade de via alternativa gratuita para a cobrança de pedágio em rodovias sob o regime de concessão.

C) Uma Única Decisão Discrepante

106. Verifica-se, no entanto, que, na contra-mão da posição jurisprudencial majoritária, foi prolatada, recentemente, pelo Superior Tribunal de Justiça, decisão em sentido contrário, apoiada em posições, já ultrapassadas, que foram adotadas, no passado, dentro de outro contexto político e econômico. Reproduzimos, a seguir, o trecho do acórdão do qual foi relator o Ministro Garcia Vieira:

"A cobrança de pedágio somente poderá ser considerada legítima se for garantido ao cidadão o tráfego por via alternativa de forma gratuita." 3

107. Fundamentou-se o julgado unicamente em interpretação feita do art. 150 . V , da Constituição Federal, considerando que a imposição do pedágio acaba por impedir o trânsito das pessoas com seus bens, pelas rodovias, quando não existir outra estrada para o mesmo destino, trazendo, em benefício desse entendimento, a interpretação segundo a qual:

"Não é razoável que se estabeleça pedágio em um único caminho de destino a um deter- minado território nacional, pois que tal fato, impedindo o trânsito do cidadão com um de seus bens (automóvel, caminhão, etc.), viola diretamente o princípio federativo.

Está implícito na nossa Constituição Federal, pois, que a cobrança do pedágio pressupõe a existência de outro caminho onde o cidadão, possa, de forma gratuita, passar com seus bens."

108. A doutrina e a jurisprudência, no entanto. ao inverso do que foi sustentado pelo relator do mencionado acórdão. conforme antes ressaltado, vem afirmando, com ênfase, a função da lei de regular o uso da rodovia e estabelecer se ele será gratuito ou oneroso, o que não implica afirmar que o trânsito está impedido, ou que não haja liberdade de locomoção.

109. O pagamento de uma determinada tarifa pela prestação do serviço oferecido nas rodovias pedagiadas não pode se confundir com imposição tributária, estabelecida indistintamente, para o efeito de circulação de pessoas e de seus bens.

110. Volta-se, nesse ponto, à própria natureza jurídica do pedágio, repetidas vezes confirmada pelos doutrinadores e pelos nossos magistrados.

111. Antes mesmo da promulgação da Lei de Concessões, a questão foi tratada pelo Supremo Tribunal Federal, quando o Ministro Ilmar Galvão consignou em voto proferido em ação direta de inconstitucionalidade que:

"Uma obra pública pode ser feita por particulares ou mesmo por particulares ser conservada e até explorada. Em troca, pode o Estado dar-lhes em concessão a administração da estrada, permitindo-lhes cobrar precos pela passagem. Reconhece, portanto, que o pedágio pode revestir a natureza de preço público, e aí parece ter identificado a sua verdadeira natureza."

1 TJ/RS, Apelação Cível n 598041804, Segunda Câmara Cível. Relator Des. João Armando Bezerra Campos, j. 31.03 .99$.

2 TJ/SP. Apelação Cível n. 244.842, Relator Des. Barbosa Pereira Filho, j. 25.09.75.

3 Trecho da ementa de Acórdão emanado do Recurso Especial n. 417.804 - PR (2002/0018047-0). 
112. Em seguida, o eminente Ministro concluiu:

"Assim sendo, parece fora de dúvida que se está diante de preço público, ou tarifa, seja, de 'retribuições facultativas da aquisição de bens ou da utilização de serviços, transferidos ou prestados pela Administração Pública ou por seus delegados ou mesmo por particulares, a quem os adquira ou os utilize voluntariamente." ।

113. Não nos parece, pois, persistir qualquer dúvida acerca da constitucionalidade da cobrança do pedágio, que, efetivamente, não tem o condão de impedir a circulação de pessoas e de seus bens, diversamente do que ocorreria com a imposição de barreiras, através de exigências tributárias.

114. Efetivamente, consoante ressaltado no curso deste parecer, as disposições do art. 150, $\mathrm{V}$, não podem ser examinadas isoladamente, mas em conjunto com as normas contidas no art. 175 da Carta Magna, que prevê a viabilidade jurídica da cobrança do pedágio para atender ao custo de conservação e melhoramentos das vias de transportes. O que está vedado constitucionalmente é a utilização de tributo que represente uma barreira ao tráfego interestadual ou intermunicipal, o que nada tem a ver com o pedágio, como vimos.

115. Com a devida vênia, o posicionamento firmado no acórdão relatado pelo Ministro Garcia Vieira, além de restringir-se à interpretação de preceitos constitucionais, de competência exclusiva do Colendo Supremo Tribunal Federal, manifestou entendimento já superado pela doutrina e pela farta jurisprudência sobre a matéria, além de se afastar da atual realidade das concessões no Brasil.

116. Pode-se afirmar, sem dúvida, que as disposições do inciso III, do art. $7^{\circ}$, e do $\$ 1^{\circ}$, do art. $9^{\circ}$, da Lei das Concessões, que pareciam dar respaldo à tese sustentada no mencionado acórdão do Superior Tribunal de Justiça, tiveram a sua redação aprimorada para eliminar qualquer dúvida a respeito. Como antes se viu, há farta jurisprudência confirmando o entendimento de que não é exigível. sem disposição legal expressa, a existência de via alternativa.

\section{$X$. DAS CONDIÇÕES DA VIA ALTERNATIVA}

117. Muito embora não haja a obrigatoriedade constitucional ou legal da existência de via alternativa, consoante demonstramos anteriormente, são raros os trechos pedagiados de rodovias concedidas que não dispõem de estrada alternativa.

118. Evidentemente, entretanto, as vias alternativas não ostentam as mesmas condições de manutenção e trafegabilidade das rodovias pedagiadas, objeto de concessão. Geralmente tratam-se de alternativas mais longas, muitas vezes precárias, nas quais os custos decorrentes de sua utilização (problemas mecânicos, desgaste dos pneus, consumo de combustível, etc ...) não compensa o seu uso como rota alternativa à rodovia pedagiada.

119. Note-se que o pedágio, como já asseveramos, foi a fórmula encontrada pelo Estado para construir e disponibilizar à população as estradas e rodovias em adequadas condições de uso. Trata-se de uma compensação pelo serviço público prestado pelas concessionárias.

120. Partindo dessa premissa, conclui-se que não se pode exigir a manutenção das rodovias alternativas - não pedagiadas - nas mesmas condições de uso e trafegabilidade das rodovias concedidas. Primeiramente, a manutenção de duas estradas em condições idênticas afigura-se materialmente impossível. Ademais, tal exigência seria a falência do instituto da concessão de rodovias no Brasil, na medida em que ninguém se utilizaria das estradas pedagiadas havendo alternativa gratuita, em condições idênticas. Por fim, sem o pedágio não há recursos disponíveis para a realização da manutenção da estrada - via alternativa - em condições sequer semelhantes daquelas que foram objeto de concessão, onde os recursos advindos da cobrança do 
pedágio contituem, justamente. a contraprestação devida ao concessionário pela implementação de melhorias e conservação da estrada.

121. Como se vê, as melhores condições das rodovias concedidas servem, justamente, de estímulo à sua utilização pelo usuário, o qual, entretanto, quando dispõe de via alternativa — não obstante a inexistência de obrigatoriedade da mesma - tem a opção de atingir o seu destino utilizando-se da rodovia concedida - contribuindo. através do pagamento do pedágio, para a manutenção da estrada em boas condições de uso e trafegabilidade ou, então, utilizando-se da via alternativa, assumindo, nesse caso, os ônus decorrentes da sua escolha.

\section{CONCLUSÕES}

122. Dentro do contexto econômico atual, em que, em razão do déficit de infra-estrutura, o Estado passou a delegar a particulares o seu dever de realizar obras e prestar serviços de interesse da sociedade, não poderia ser diferente a letra da lei. A exigência de disponibilizar aos usuários uma rodovia gratuita poderia implicar em inviabilidade da prestação do serviço público, na medida em que faltariam recursos orçamentários para fazer frente aos investimentos necessários à tal empreendimento.

123. Ora, se o Estado não possui recursos suficientes para construir e preservar estradas e, justamente por isso. contrata com o particular para que este invista capital privado em benefício do interesse da coletividade, garantindo a este a exploração da obra como pagamento pelo investimento realizado, está claro que a exigência de disponibilização de via alternativa para a cobrança de pedágio afastaria, em muitos casos, a própria viabilização da obra e da existência de rodovias adequadas e seguras ao tráfego.

124. Afinal, consistindo a cobrança de pedágio na maneira através da qual o concessionário remunera-se pelo investimento aplicado na obra e no serviço, como poderia este subsumir-se no dever do Estado de prestar o ser- viço concedido, sem que the fosse assegurado o direito de cobrar o pedágio independentemente da existência de estrada alternativa para o usuário?

125. E justamente em razão da sua viabilidade jurídica é que as disposições constantes dos editais de licitação e dos contratos de concessão firmados entre os concessionários e o Poder Concedente expressamente asseguram aos concessionários de rodovia o direito de cobrar o pedágio, o que fazem baseados na confiança que depositam no Poder Público e na manifestação de vontade do mesmo.

\section{RESPOSTA AO QUESITO}

126. A) QUESITO ÚNICO:

"É requisito indispensável para a cobrança de pedágio em rodovia objeto de concessão a existência de via alternativa gratuita de trânsito?".

\section{RESPOSTA AO QUESITO}

127. Não. A existência de via alternativa não é condição para a concessão de obra pública e, conseqüentemente, para a cobrança do pedágio.

128. Foram analisados no presente estudo os preceitos da Constituição Federal e as disposições constantes da legislação de concessões, para o fim de responder a indagação formulada pela Consulente.

129. Ficou assentado que a norma constitucional que assegura o direito de liberdade de locomoção (CF, art. $\left.5^{\circ}, \mathrm{XV}\right)$ tem eficácia contida, podendo ser delimitada pela legislação ordinária.

130. Verificamos que não há no sistema jurídico brasileiro qualquer dispositivo legal que condicione a cobrança de pedágio à existência de via alternativa de trânsito. Ao contrário, a Lei de Concessões exclui expressamente a exigência de disponibilização de serviço alternativo para a cobrança de tarifa pelo concessionário (art. $9^{\circ}, \S 1^{\circ}$ ).

131. Diante de todo o exposto, concluímos que, dentro do ordenamento jurídico em vi- 
gor, se o usuário optar por fazer uso da rodovia objeto de concessão, deverá pagar o preço pela sua utilização - o pedágio - independentemente da existência de rodovia alternativa gratuita, assim como o faz quando se utiliza de qualquer outro serviço público prestado por concessionária.

132. Conforme exposto, no atual contexto político e econômico. em que o Estado não possui infra-estrutura para cumprir seu dever de construir e conservar estradas, a delegação de tal atividade ao particular, através da denominada "concessão de obras públicas". torna-se imprescindivel para atender os interesses da sociedade.

133. Como o capital investido pelo concessionário no interesse público deve ser remunerado, a legislação de concessões, aplicando os princípios da equiidade e da justa distribuição dos encargos, exigindo a manutenção do equilíbrio econômico e financeiro do contrato, determina que o ônus de ressarcir e com- pensar os investimentos realizados pelas concessionárias para a realização de obras e a prestação de serviços públicos seja arcado pelos usuários das rodovias, sob a forma de pagamento de tarifa - o pedágio.

134. O pedágio consiste, pois, na tarifa paga pelo usuário em virtude da utilização da rodovia, construída e/ou mantida pela iniciativa privada que recebeu delegação do poder concedente para tal atividade. Em outras palavras, o pedágio constitui a principal fonte de remuneração do concessionário, que é essencial para a prestação do serviço e, por outro lado. configura condição imposta ao usuário para a utilização do serviço público concedido.

$$
\text { É o nosso parecer. }
$$

Arnoldo Wald Advogado, inscrito na OAB.RJ $n^{\circ} 6.582$ e OAB.SP n 46.560.A.; Professor Catedrático de Direito Civil da Faculdade de Direito da Universidade do Estado do Rio de Janeiro 